\title{
The Last Month of Szent-Györgyi in Groningen
}

\author{
JAAP J. BEINTEMA \\ Department of Biochemistry \\ University of Groningen \\ Nijenborgh 4 \\ 9747 AG Groningen, The Netherlands \\ E-mail: j.beintema@home.nl
}

\begin{abstract}
Albert (von) Szent-Györgyi started his studies on biological oxidation processes - which also resulted in the discovery of vitamin $\mathrm{C}$, for which he received the Nobel Price in 1937 - in the Laboratory of Physiology of the University in Groningen in 1922-1926. These studies were later continued in Cambridge (UK) and Szeged (Hungary). When he had already received the invitation as well as the financial means to come and work in Cambridge, he still did experiments in Groningen to find out whether the adrenal extract, isolated by him and later found to be a major source of vitamin C, contained the hormone essential for the survival of cats whose adrenals were removed. He was rather upset by the negative results of this experiment, judging by the recollections of a former student of his. This history constitutes an interesting example of the difference between serendipitous discovery and planned invention.
\end{abstract}

Keywords: Szent-Györgyi, vitamin C, Groningen, hormones of the adrenal cortex

Albert (von) Szent-Györgyi started his studies on biological oxidation processes, including the discovery of vitamin $\mathrm{C}$, for which he received the Nobel Price in 1937, in the Laboratory of Physiology of the University in Groningen in 1922-1926. The results of these studies are described in six papers in Biochemische Zeitschrift (Szent-Györgyi; 1924, 1925a, b, c, 1927a, b). Szent-Györgyi described (Szent-Györgyi, 1963, p. 6) how he thought he could tackle a certain biochemical problem in Groningen, and he embarked on biological oxidations. At the time a violent controversy raged between $\mathrm{O}$. Warburg and $\mathrm{H}$. Wieland and their followers. The former thought that oxygen activation was the most essential feature of respiration, whereas Wieland claimed it was $\mathrm{H}$-activation. Szent-Györgyi proved that both processes were involved and that these processes came in a number of steps. These ideas were later completed by Krebs and are the foundations of the so-called "Krebs cycle." 
Ironically, no one in Groningen seemed to appreciate the importance of the research work by Szent-Györgyi; neither was he given the assistance he needed (Moss, 1988, p. 42). In July 1925 he wrote a paper on the respiration of plants (Szent-Györgyi, 1925c) which may be considered as the first demonstration of a compound later identified as vitamin C. The newly appointed professor of Physiology in Groningen, F.J.J. Buytendijk, thought the paper should be thrown in the wastepaper basket (Moss, 1988, p. 48). The situation in Groningen depressed Szent-Györgyi so much that he thought of giving up scientific research altogether. He was a relative beginner in science; he had no money and no foreign diplomas (Szent-Györgyi, 1963, p. 7). By way of a farewell to science he decided to attend the International Physiological Congress in Stockholm (August 1926), where he heard the famous biochemist F.G. Hopkins in his presidential address mention his name three times. This resulted in an invitation to continue his studies in Cambridge, and on 15 October 1926 he received a message that he had been awarded a grant from the Rockefeller Foundation, to start January 1927.

On 13 October, he left his house in the Koninginnelaan 57a in Groningen, where he had lived with his family for almost 4 years, and moved in with good friends (an upper-class family) elsewhere in Groningen. His wife and daughter had probably returned earlier to Hungary. On 2nd December he officially left Groningen with his family and traveled to Cambridge (UK).

One would expect that in those last few months in Groningen, having received this honourable invitation from Cambridge, he had a more relaxed time. But this was not the case. In the last experiment performed in Groningen he tried to demonstrate the hormonal nature - essential for life - of a reducing compound in extracts from bovine adrenals obtained from the local slaughterhouse. This is described in a dramatic account by his student R. Zondervan (1903-2002), who studied chemistry in Groningen 80 years ago and wrote this memoir not so long ago, in 1995 (translated by the author):

Recollections by R. Zondervan:

At the end of November, 1926, Albi (Szent-Györgyi) came up unexpectedly to our table of senior students in a well-known restaurant in Groningen, called Baulig, where I met him regularly before I started research work with him earlier that year. He said: "Very nice to see you here, because I have to ask 
you something: will you be celebrating "Sinterklaas" next week?" (Saint Nicolas Eve is a traditional family festivity on 5 December in the Netherlands.) To this rather unexpected question I could answer directly: "Our family has just decided to skip the Sinterklaas festivities this year." "Very good," said Albi "because every one else I asked said: "No, on 5 December I'll be busy in the evening." So I asked wonderingly: "What is happening on 5 December then?" He said: "I hope you can assist me that evening, because on exactly that day I shall receive six cats to conduct experimental work on, and I have made a tight schedule how to work with them. It's wonderful that you are available, because on my own I will not be able to remove adrenals from six cats, but between the two of us we'll manage." I told him that I had no operating experience, but that was not necessary he said; I was to assist him and act as an anaesthetist. The scheme was as follows: first operate on the six cats in the evening of 5 December, work up fresh cuttings from the slaughterhouse to what we called "the preparation" on the day after that, and then the cats had three more days to decline in condition before the preparation had lost all power again. We worked according to plan. On the evening of "Sinterklaas" we worked in the completely empty laboratory, and when we decided to have a beer at midnight, being a little tired, the cats in their separate cages were recovering from their operations. The next day I went back to find out what the situation was. Albi was busy working. One cat was in a very bad state, and unlikely to survive the operation. Every day I came to have a look at the progress of the experiment. Unfortunately, it did not proceed as expected. Five cats recovered rather well from the operation. However, the preparation became less active and, much to Albi's despair, it had hardly any effect any more at the end of that week. Four more days elapsed before he had a new preparation again. In fact, it was a piece of good luck that only one cat died in those four days. The health of the other four cats gradually deteriorated, and they did not react to the injection that should have prolonged their lives. Only one cat survived. When, moreover, the preparation appeared to be inactive in the rabbit test -a kind of quality check- Albi began to panic, which did not surprise me: his wife had left Groningen, and he had moved a couch from his house to the laboratory and now lived virtually next to the cats' cage. Raised by his alarm clock, he checked the 
cat every hour. How he got his meals and drinks, I did not know, but on a bad day he suddenly turned up at our table in Baulig. It was evident that he was sick and tired of observing the only surviving cat at all hours of the night. When I showed surprise at his presence, he reacted by saying that he had fled the laboratory for half an hour to have a glass of beer because the condition of the last cat had also considerably worsened that day. He intended to be there all night to wait for the best moment to give an injection. When I went to the Physiology Laboratory the next day to have a look, I was stopped by the assistant, who asked me: "Do you know where Dr. von Szent-Györgyi is hanging out?" I asked: "Why do you ask? He should be here" "No, there is no one downstairs. Just a dead cat in its cage; in his room there's a lot of broken glassware but no further traces of him. He did not sleep here, because his couch is in the upright position. I also tried to phone him at home, but there was no answer." Only after 3 days I succeeded in contacting Albi again: he was still looking haggard, but he told me briefly what had happened. When he had returned in the laboratory that evening, after half an hour, the last surviving cat was lying dead in its cage, and he had gone completely mad and had run away; he didn't remember where. He had been away for several days, but said he remembered little about the previous days. When I came back to work at the laboratory the following Monday, I had a talk with Albi about whether to start his research again or not. He told me that he could "perhaps" start again in Cambridge where there was a real Department of Biochemistry and where he could obtain fresh cuttings from the London slaughterhouse every day. In addition, there would be the opportunity to study the composition of the new compound discovered by him and he would also have sufficient help to purify it.

It is interesting to compare this report by Zondervan with the "positive" description of the experiment by Szent-Györgyi himself, in which the scientist describes the removal of adrenal glands from six cats in a postscript to the final paper about his research in Groningen (SzentGyörgyi, 1927b): After the operation the condition of some of the cats improved temporarily. But three cats died within two days. The other ones died after 7 and 8 days, which meant that the operation had been successful. But injection of compound $\mathrm{C}_{\mathrm{XII}}$ (the reducing compound from adrenals) or the primary methanol extract from bovine adrenals 
could not prolong the life of the cats, indicating that $\mathrm{C}_{\mathrm{XII}}$ is not identical with the adrenal hormone.

This paper was received by Biochemische Zeitschrift on 18th December 1926. If the report by Zondervan - stating that the operation of the cats took place on 5th December - is correct, the last cat died 8 days later on 13th December, and Szent-Györgyi could not be located until 16 December. But on 16th or 17th December his final paper had already been dispatched (probably after adding the postscript with the experiment about the failure to demonstrate the hormonal nature of compound $\mathrm{C}_{\mathrm{XII}}$ ).

Why had Szent-Györgyi been so upset by the disappointing results of his final experiment performed in Groningen? He was probably not entirely confident about showing his scientific abilities in his new working surroundings in Cambridge, the more so as an earlier visit of 6 weeks to Cambridge at the beginning of 1925 had not been very successful (Moss, 1988, p. 47). He hoped that on arrival in Cambridge he would be able to produce evidence that the substance isolated by him from adrenals was the hormone essential for survival after adrenalectomy. But this was not the case. Four years later, other scientists did a very similar experiment on adrenalectomized cats with a positive result (Swingle and Pfiffner, 1930) and these investigations were followed up by those of others, leading to the award of the Nobel prize in 1950 to E.C. Kendall, T. Reichstein and P.S. Hench for their discoveries relating to the hormones of the adrenal cortex, their structure and biological effects. What was the difference between the adrenal extracts prepared by Szent-Györgyi and by Swingle and Pfiffner? Szent-Györgyi extracted the adrenals with methanol, followed by precipitation with lead acetate and extraction of the precipitate with dilute acid, followed by neutralization. Swingle and Pfiffner made extracts with 95 and $80 \%$ ethanol, concentrated them, followed by extraction with acetone, removal of this solvent and distribution between $70 \%$ ethanol and petroleum ether. They obtained a water soluble preparation after distillation of the petroleum ether. These conditions suggest that the preparation of SzentGyörgyi was more hydrophilic and contained a carbohydrate, which was later identified as hexuronic acid (vitamin C), whereas the preparation of Swingle and Pfiffner was more lipophilic and contained the adrenal cortex hormones. A further complication in Szent-Györgyi's work was that he used a rabbit test to study the biological activity of his preparation, which probably reacted positively with contaminating adrenaline (Szent-Györgyi, 1927b). 
Szent-Györgyi continued his studies on the reducing agent found in Groningen, isolated it from animal and plant sources and crystallized it (Szent-Györgyi, 1928). It was called hexuronic acid. The editors of Biochemical Journal did not allow him to call it ignose or godnose (Szent-Györgyi, 1963, p. 7). At a later stage, when he was invited by Kendall to stay in the Mayo Clinic in Rochester, Minnesota in the United States, he succeeded in isolating larger quantities $(25 \mathrm{~g})$. These were passed on to W.N. Haworth, the great carbohydrate chemist, who undertook the constitution analysis (Szent-Györgyi, 1963, p. 8), and who also received the Nobel Price for Chemistry in 1937, for his work on carbohydrates and vitamin $\mathrm{C}$.

In 1932 Szent-Györgyi was appointed professor in medical chemistry at the University of Szeged in Hungary. At that time the hexuronic acid was still on his shelf as a substance with unknown functional properties. But an American-born Hungarian, J. Swirbely, came to work in Szeged with Szent-Györgyi; and proposed to find out if this compound could be identical to vitamin C. This proved to be correct, and it was confirmed after isolation of larger quantities taken from Hungarian paprikas (red peppers), and then hexuronic acid could be renamed ascorbic acid.

The discovery of vitamin $\mathrm{C}$ by Szent-Györgyi is an interesting example of the difference between findings with a preconceived objective and serendipitous discoveries. Just as Columbus discovered America, assuming he had found a new route to Asia, Szent-Györgyi thought that he had discovered an essential adrenal hormone, but the active substance he really found was vitamin $\mathrm{C}$, an essential compound in human nutrition, occurring ubiquitously in living organisms.

\section{Acknowledgements}

I thank Mr. Pek van Andel for giving me a copy of R. Zondervan's recollections and $\mathrm{Mr}$. I. Wierenga for carefully reading the manuscript and correction of the English.

\section{References}

Moss, R. W. 1988. Free Radical. Albert Szent-Györgyi and the Battle Over Vitamin C. New York: Paragon House Publishers.

Swingle, W. W. and Pfiffner, J. J. 1930. "An Aqueous Extract of the Suprarenal Cortex Which Maintains the Life of Bilaterally Adrenalectomized Cats." Science 71: 321. 
von Szent-Györgyi, A. 1924. "Über den Mechanismus der Succin- und Paraphenylendiaminoxydation. Ein Betrag zur Theorie der Zellatmung." Biochemische Zeitschrift 150: 195-210.

von Szent-Györgyi, A. 1925a. "Zellatmung.II. Mitteilung: Der Oxydationsmechanismus der Milchsäure." Biochemische Zeitschrift 157: 50-66.

von Szent-Györgyi, A. 1925b. "Zellatmung. III. Mitteilung: Reaktivierungsversuch mit künstlichen Kofermenten." Biochemische Zeitschrift 157: 67-84.

von Szent-Györgyi, A. 1925c. "Zellatmung. IV. Mitteilung: Über den Oxydationsmechanismus der Kartoffeln." Biochemische Zeitschrift 162: 399-412.

von Szent-Györgyi, A. 1927a. "Zellatmung. V. Mitteilung: Über den Oxydationsmechanismus einiger Pflanzen." Biochemische Zeitschrift 181: 425-432.

von Szent-Györgyi, A. 1927b. "Zellatmung VI. Mitteilung: Zur Funktion der Nebennierenrinde and über die Substanz C $_{\mathrm{XII}}$." Biochemische Zeitschrift 181: 433-437.

Szent-Györgyi, A. 1928. "CLXXIII. Observations on the Function of Peroxidase Systems and the Chemistry of the Adrenal Cortex." Biochemical Journal 22: $1387-1409$.

Szent-Györgyi, A. 1963. "Lost in the Twentieth Century." Annual Review of Biochemistry 32: 1-14. 